\title{
BOTÂNICA E FISIOLOGIA/ BOTANY AND PHYSIOLOGY ANTIOXIDANT ACTIVITY AND PHYSICOCHEMICAL PARAMETERS IN 'CUERNAVAQUEÑA' MEXICAN PLUM (Spondias purpurea L.) AT DIFFERENT RIPENING STAGES ${ }^{1}$
}

\author{
ADABELLA SUÁREZ VARGAS², PORFIRIO JUÁREZ-LÓPEZ ${ }^{3}$, VÍCTOR LÓPEZ-MARTÍNEZ ${ }^{4}$, \\ LAURA JOSEFINA PÉREZ FLORES ${ }^{5}$, \\ DAGOBERTO GUILLÉN SÁNCHEZ ${ }^{6}$, IRÁN ALIA-TEJACAL ${ }^{7 *}$
}

\begin{abstract}
Mexican plum (Spondias purpurea L.) 'Cuernavaqueña' was harvested at four ripening stages, with the aim of evaluating the concentration of bioactive compounds and antioxidant capacity in the pulp and the epicarp. The highest ethylene production $\left(9.43 \mu \mathrm{L} \mathrm{kg} \mathrm{h}^{-1}\right)$ and total soluble solids concentration (23.9 ${ }^{\circ}$ Brix) was observed in the fully ripe stage. Titratable acidity was higher in green stage compared to other analyzed ripening stages in both pulp $(0.48 \%)$ and epicarp $(0.32 \%)$. Fully ripe plum epicarp presented the highest content of total phenols (GAE $190 \mathrm{mg} \mathrm{g}^{-1}$ ), flavonoids (QE $214 \mathrm{mg} \mathrm{g}^{-1}$ ), and carotenoids (853 mg $\left.\mathrm{g}^{-1}\right)$ compared to other ripening stages. The antioxidant capacity was higher in the epicarp of the fully ripe fruit compared to the other ripening stages: DPPH $(1087 \mu \mathrm{M}$ TE $/ 100 \mathrm{~g})$, ABTS $(1534 \mu \mathrm{M} \mathrm{TE} / 100 \mathrm{~g})$, and FRAP $(1764 \mu \mathrm{M}$ TE/100 g). Significant correlations $(\mathrm{r}=0.60 * * *$ to $0.95 * *)$ between bioactive compounds concentrations and antioxidant activity were obtained.
\end{abstract}

Index terms: Spondias purpurea; bioactive compounds; antioxidant activity.

\section{ATIVIDADE ANTIOXIDANTE E PARÂMETROS FISICOQUÍMICOS DA AMEIXA MEXICANA “CUERNAVAQUEÑA" (Spondias purpurea L.)EM DIFERENTES ESTÁGIOS DE AMADURECIMENTO}

RESUMO - A ameixa mexicana (Spondias purpurea L.) 'Cuernavaqueña' foi colhida em quatro estádios de amadurecimento com o objetivo de avaliar a concentração de compostos bioativos e capacidade antioxidante da polpa e do epicarpo. A maior produção de etileno $\left(9,43 \mathrm{~mL} \mathrm{~kg} \mathrm{~h}^{-1}\right)$ e concentração total de sólidos solúveis $\left(23,9^{\circ}\right.$ Brix $)$ foi observada no estágio totalmente maduro. A acidez titulável foi maior no estádio verde em comparação com outros estádios de amadurecimento analisados tanto na polpa $(0,48 \%)$ como no epicarpo $(0,32 \%)$. O epicarpo da ameixa totalmente madura apresentou o maior teor de fenóis totais (GAE 190 $\mathrm{mg} \mathrm{g}^{-1}$ ), flavonóides (QE $214 \mathrm{mg} \mathrm{g}^{-1}$ ) e carotenóides (853 $\mathrm{mg} \mathrm{g}^{-1}$ ) em comparação com outros estádios de amadurecimento. A capacidade antioxidante foi maior no epicarpo do fruto totalmente maduro em comparação com os outros estádios de amadurecimento: DPPH (1087 $\mu \mathrm{M} \mathrm{TE} / 100 \mathrm{~g})$, ABTS (1534 $\mu \mathrm{M} \mathrm{TE} / 100 \mathrm{~g})$ e FRAP (1764 $\mu \mathrm{M}$ TE / $100 \mathrm{~g})$. Foram obtidas correlações significativas $(\mathrm{r}=0,60 * * *$ a $0,95 * *)$ entre as concentrações de compostos bioativos e a atividade antioxidante.

Termos para indexação: Spondias purpurea; Compostos bioativos; atividade antioxidante.

\footnotetext{
${ }^{1}$ (Paper 052-16). Received April 30, 2016. Accepted August 12, 2016.

${ }^{2}$ M.C.A Facultad de Ciencias Agropecuarias, Universidad Autónoma del Estado de Morelos. México. E-mail: adabellasuarez@yahoo.com ${ }^{3}$ Dr., Investigador de la Facultad de Ciencias Agropecuarias, Universidad Autónoma del Estado de Morelos. México. E-mail: porfiriojlopez@yahoo.com.

${ }^{4}$ Dr., Investigador de la Facultad de Ciencias Agropecuarias, Universidad Autónoma del Estado de Morelos. México. E-mail: vilomar. leo@gmail.com.

${ }^{5}$ Dra., Investigadora del Departamento de Ciencias de la Salud, Universidad Autónoma Metropolitana, México. E-mail: laujperez@ yahoo.com.mx

${ }^{6}$ Dr., Investigador de la Escuela de Estudios Superiores de Xalostoc, Universidad Autónoma del Estado de Morelos. E-mail: dagoguillen@yahoo.com.

${ }^{7}$ Dr., Investigador de la Facultad de Ciencias Agropecuarias, Universidad Autónoma del Estado de Morelos. México. *Corresponding autor:E-mail: ijac96@yahoo.com
} 


\section{INTRODUCTION}

Mexican plum, Spondias purpurea L. (Anacardiaceae), is a tropical tree with round and ovoid fruits that vary on size (from 20-50 mm) and mass (from 4 to $43 \mathrm{~g}$ ) which epicarp can be red, yellow, orange, or purple in the ripe fruit. It is considered a Mexican native species that can be found in low deciduous and semideciduous tropical forests which distribution comprises the Western coast and the Southeastern zone of the country. It is a fruit tree with a high commercial potential due to its low production cost and the fact that grows in the wild and adapts to poor and thin soils (AVITIA-GARCÍA et al., 2000). Its fruit is consumed fresh and due to its high acceptability, it has potential for commercial largescale production (BAUTISTA-BAÑOS et al., 2003). Currently, the consumption of functional foods (fruits and vegetables) associated to prevention of chronic diseases has increased. These beneficial effects are due to the presence of bioactive compounds (vitamins, enzymes, carotenoids, flavonoid, and phenolic compounds) with antioxidant properties (HOOPER and CASSIDY, 2006; ISABELLE et al., 2010) that neutralize harmful molecules such as free radicals, that interact and destabilize important macromolecules like proteins, nucleic acids and lipids causing degenerative diseases in the organism (NIVA, 2007). There are different methods that use chromogenic compounds (DPPH, FRAP, ABTS and others) to determine the antioxidant capacity (BRAND-WILLIAMS et al., 1995; BENZIE and STRAIN, 1996; RE et al., 1999) of a product to neutralize reactive oxygen species (ROS) and free radicals (PRIOR et al., 2005). The studies that report the presence of bioactive compounds with antioxidant activity in Mexican native fruits are scarce. The objective of this research was to quantify the antioxidant capacity in pulp and epicarp of the Mexican plum 'Cuernavaqueña', a Mexican native fruit, at four different ripening stages and correlate it with the presence of bioactive compounds.

\section{MATERIALS AND METHODS}

Mexican plum 'Cuernavaqueña' fruits were harvested in a comercial orchard located in Buenavista, Cuernavaca, Morelos, Mexico (18 $56^{\prime} 55.71^{\prime \prime} \mathrm{N}, 99^{\circ} 18^{\prime} 39.67^{\prime \prime} \mathrm{W}, 1987$ m.a.s.1.) in September 2014.

Fruits were sorted by color of the epicarp in four groups of 50 fruits each according to their ripening stage: green ( $100 \%$ green epicarp), $1 / 2$ green
( $75 \%$ green epicarp), $3 / 4$ ripe ( $25 \%$ green epicarp), and fully ripe ( $0 \%$ green epicarp). Fruits were disinfected with a $1 \%(\mathrm{v} / \mathrm{v})$ hypochlorite solution and then let to stand at room temperature $\left(22 \pm 2{ }^{\circ} \mathrm{C}\right.$ and $60 \pm 2$ $\% \mathrm{RH}$ )

Color parameters lightness $\left(\mathrm{L}^{*}\right)$, chromaticity $\left(\mathrm{C}^{*}\right)$, and angle hue $\left(\mathrm{h}^{\circ}\right)$ were determined in the plum epicarp using a Spectrophotometer (X-Rite $3290^{\circledR}$, USA). Measurements were taken from three different parts of each fruit (MCGUIRE, 1992). Twenty fruits from each ripening stage were evaluated.

Respiration rate $\left(\mathrm{CO}_{2}\right.$ production $)$ and ethylene production were quantified using a static system (MENDOZA-WILSON and BÁEZSAÑUDO, 2000) which consisted in placing two fruits of known mass (Average $70 \mathrm{~g}$ ) in $145 \mathrm{~mL}$ glass jars hermetically sealed for $2 \mathrm{~h}$. Afterwards, $1 \mathrm{~mL}$ of the headspace was taken from the jars and injected to a gas chromatograph (Agilent Technologies 7890A GC) with a porous layer open column simultaneously connected to a flame ionization detector (FID, 170 ${ }^{\circ} \mathrm{C}$ ) and to a thermal conductivity detector (TCD, $\left.170^{\circ} \mathrm{C}\right) ; \mathrm{N}_{2}\left(2 \mathrm{~mL} \mathrm{~min}^{-1}\right)$ was used as the carrier gas. The injector and the oven were maintained at 150 and $80^{\circ} \mathrm{C}$, respectively, during measurements. Commercial standards of $\mathrm{CO}_{2}(460 \mathrm{ppm})$ and ethylene (100 ppm) (Quark INFRA $\left.{ }^{\circledR}\right)$ were used for quantification. The experimental unit was of two fruits with six replicates for each ripening stage.

Soluble solids (SS) were determined from the juice of the fruit obtained with a Super Extractor (ATAGO ${ }^{\circledR}$ ) using a refractometer (ATAGO PAL$1^{\circledR}$, Japan). Results are reported in ${ }^{\circ}$ Brix. Titratable acidity (TA) was determined by the AOAC method (1995) in the epicarp and the pulp; sample was titrated with $0.1 \mathrm{~N} \mathrm{NaOH}$ using phenolphthalein as indicator. Results are expressed as percentage of citric acid. Flavor index (FI) was determined as the ratio of SS and TA (SS/TA) in the pulp and the epicarp. Ten fruits from each ripening stage were evaluated.

Total phenols concentration was determined by the Folin-Ciocalteau method (SINGLETON et al., 1999). One gram of tissue (pulp and epicarp) was homogenized with $20 \mathrm{~mL}$ of distilled water in a test tube using an Ultra Turrax $\left(\right.$ IKA $\left.^{\circledR}\right)$. The homogenate was filtered and $0.5 \mathrm{~mL}$ were mixed with $2.5 \mathrm{~mL}$ of Folin-Ciocalteu reagent $(1: 10 \mathrm{v} / \mathrm{v})$ and let to stand for $5 \mathrm{~min}$, then $2 \mathrm{~mL}$ of sodium carbonate $(7.5 \%$ $\mathrm{w} / \mathrm{v}$ ) were added and let to stand for $2 \mathrm{~h}$. Afterwards, absorbance at $760 \mathrm{~nm}$ was measured using a spectrophotometer (HACH DR 5000 ${ }^{\circledR}$ ). Results are expressed as mg gallic acid equivalents per $100 \mathrm{~g}$ (mg GAE $100 \mathrm{~g}^{-1} \mathrm{fw}$ ). 
Total flavonoids were determined using the methodology reported by Arvouet-Grand et al. (1994). Pulp and epicarp samples $(0.5 \mathrm{~g})$ were homogenized with $10 \mathrm{~mL}$ of methanol using an Ultra Turrax $\left(\mathrm{IKA}^{\circledR}\right)$. The homogenate was filtered and 2 $\mathrm{mL}$ were mixed with $2 \mathrm{~mL}$ of $2 \%(\mathrm{w} / \mathrm{v})$ aluminum chloride and let $15 \mathrm{~min}$ in the dark. Afterwards, absorbance at $415 \mathrm{~nm}$ was measured using a spectrophotometer (HACH DR $5000^{\circledR}$ ). Results are expressed as mg quercetin equivalents (QE) per 100 $\mathrm{g}$ of fresh weight (mg QE $\left.100 \mathrm{~g}^{-1}\right)$.

Extraction and quantification of carotenoids was performed by the methodology described by Rodríguez-Amaya and Kimura (2004). One gram of sample was homogenized with $15 \mathrm{~mL}$ of cold acetone using an Ultra Turrax (IKA ${ }^{\circledR}$ ) and the homogenate was filtered, then, $20 \mathrm{~mL}$ of hexane and $100 \mathrm{~mL}$ of distilled water were added and let to stand until two phases were separated. The aqueous phase (lower phase) was discharged and the upper phase was recovered, $100 \mu \mathrm{L} 10 \mathrm{~N} \mathrm{NaOH}$ were added and then, it was washed with $100 \mathrm{~mL}$ of distilled water four times. Afterwards, the extract was filtered using a filter paper coated with a layer of anhydrous sodium sulfate to remove water residues. Final volume was measured and absorbance at $452 \mathrm{~nm}$ recorded using a spectrophotometer (HACH DR $5000{ }^{\circledR}$ ). Samples that had an absorbance higher to 0.8 were diluted with hexane at a $1: 1 \mathrm{v} / \mathrm{v}$ ratio. Total carotenoids content was calculated using the following formula:

Total caratenoids content $=\frac{A \times \text { volume }(m L) \times 10^{4}}{A_{1 \mathrm{~cm}}^{1 \%} \quad x \text { sample weight }(g)}$

Where $\mathrm{A}=$ absorbance, volume $=$ total volume of the extract and $A=$ absorption coefficient of $\beta$-carotene in hexane (2592). Results are expressed as $\mu \mathrm{g} 100 \mathrm{~g}^{-1} \mathrm{fw}$.

Samples for measuring antioxidant capacity were prepared by homogenizing $1 \mathrm{~g}$ of tissue (pulp and epicarp) with $10 \mathrm{~mL}$ of distilled water. The DPPH method described by Brand-Williams et al. (1995) with slight modifications was used. In a $3 \mathrm{~mL}$ quartz cell, $6,1 \times 10^{-5} \mathrm{M}$ methanolic DPPH solution (Sigma Aldrich, USA) was made to react with 100 $\mu \mathrm{L}$ of sample solution for $30 \mathrm{~min}$ at dark. Change in absorbance at $517 \mathrm{~nm}$ was determined. Results are expressed as mg ascorbic acid equivalents (AAE) and $\mu \mathrm{M}$ Trolox equivalents (TE) $100 \mathrm{~g}^{-1}$ fresh weight.

A $1: 1 \mathrm{v} / \mathrm{v}$ solution of $7 \mathrm{mM}$ ABTS (SigmaAldrich) and $2.45 \mathrm{mM}$ sodium persulfate $\left(\mathrm{K}_{2} \mathrm{~S}_{2} \mathrm{O}_{8}\right)$ was prepared and let to stand for 16 hours. This solution was diluted with $20 \%$ ethanol until an absorbance of $0.7 \pm 0.02$ at $734 \mathrm{~nm}$ was obtained; then $3 \mathrm{~mL}$ of the ABTS solution were made to react with $50 \mu \mathrm{L}$ of sample solution for $15 \mathrm{~min}$ and absorbance was measured at $734 \mathrm{~nm}$. Results are expressed as mg ascorbic acid equivalents (AAE) and $\mu \mathrm{M}$ Trolox equivalents (TE) $100 \mathrm{~g}^{-1}$ fresh weight (RE et al., 1999).

The method developed by Benzie and Strain (1996) was followed. FRAP (ferric reduction) reagent was prepared (Tripyridil-s-triazina, $\mathrm{FeCl}_{3}$ and acetate buffer) and $1.8 \mathrm{~mL}$ of the reagent were mixed with $140 \mu \mathrm{L}$ distilled water and $60 \mu \mathrm{L}$ of sample solution and incubated for $30 \mathrm{~min}$ at $37{ }^{\circ} \mathrm{C}$. Afterwards, absorbance at $593 \mathrm{~nm}$ was measured. Results are expressed as $\mathrm{mg}$ ascorbic acid equivalents (AAE) and $\mu \mathrm{M}$ Trolox equivalents (TE) $100 \mathrm{~g}^{-1}$ fresh weight.

Total phenols, flavonoids and carotenoids, as well as antioxidant capacity were determined in six replicates. Each replicate was obtained from a different experimental unit that consisted in two fruits.

Data were analyzed by analysis of variance (ANOVA) and Tukey mean comparisons $(P<$ 0.05 ) using the software SAS version 9.2. Pearson correlation coefficient analysis was performed between the bioactive compounds and the antioxidant activity.

\section{RESULTS AND DISCUSSION}

There were no significant differences in $\mathrm{CO}_{2}$ production among the different ripening stages; the average value of this parameter was $1.11 \mathrm{~mL}$ $\mathrm{kg} \mathrm{h}^{-1}$ (Table 1). In a previous study, Pérez et al. (2004) did not observe significant differences in the respiration rate of Mexican plum fruit from Oaxaca at three different ripening stages: green, $1 / 2$ yellow, and $3 / 4$ yellow. A similar response was reported by Kohatsu et al. (2011) in Spondias purpurea fruit grown in Brazil. In contrast, Dantas et al. (2016), Montalvo-González et al. (2011), Pareíra et al. (2000) and Osuna et al. (2011) reported a climacteric behavior in Mexican plums grown in Mexico and Brazil. Recently, Maldonado-Astudillo et al. (2014) indicated that due to the variation in the behavior of $\mathrm{CO}_{2}$ production, it is difficult to determine if Mexican plum is a climacteric fruit or not, even though physical and biochemical changes during ripening suggest it is a climacteric fruit.

Ethylene production increased with ripening stage from 3.92 to $9.43 \mu \mathrm{L} \mathrm{kg} \mathrm{h}^{-1}$, the highest production was observed in the fully ripe stage (Table 1). Pérez et al. (2004) did not determine changes in ethylene production during ripening 
of Mexican plum fruit from Oaxaca. On the other hand, Montalvo-González et al. (2011) detected a significant increase in ethylene production during ripening of yellow plum from Nayarit stored under different light conditions. In general, an increase in ethylene production acts as a trigger of fruit ripening, inducing the autocatalytic production that causes changes in color, texture, aroma, flavor, and other biochemical, physiological and physical attributes of the fruit (HIWASA-TANASE and EZURA, 2014) that the consumer consider important for its acquisition.

Color parameters in the epicarp of Mexican plum showed significant $(P<0.05)$ changes among the four ripening stages (Table 1). Similar behavior to reported to Dantas et al. (2016). In the green stage, the epicarp was green $\left(h^{\circ}=108,90\right)$, dull $\left(C^{*}=26,36\right)$ and a little bright $\left(\mathrm{L}^{*}=39.87\right)$; in the $1 / 2$ green stage the color was close to yellow $\left(h^{\circ}=93,7\right)$, less dull $\left(\mathrm{C}^{*}=34,4\right)$ and brighter; in the $3 / 4$ ripe stage, fruits showed a angle hue tending towards orange $\left(\mathrm{h}^{\circ}=\right.$ $75.27)$ with a chromaticity of $C^{*}=43.39$ and more brightness $\left(\mathrm{L}^{*}=50.3\right)$ compared to all the other ripening stages. In the fully ripe stage the color determined was tending toward red $\left(h^{\circ}=60.39\right)$, duller $\left(\mathrm{C}^{*}=40.48\right)$ and less bright $\left(\mathrm{L}^{*}=45.91\right)$ than the previous stage. Color change in Mexican plum might be due to a decrease in chlorophyll levels and an increase in carotenoids biosynthesis; however this hypothesis has not been confirmed.

Soluble solids (SS) significantly increased from the green stage $\left(5.83{ }^{\circ} \mathrm{Brix}\right)$ to the ripe stage (23.9 ${ }^{\circ}$ Brix) (Table 1). Alia et al. (2012) reported maximum values of $17.3^{\circ}$ Brix in 67 harvestings of Mexican plum from Morelos, Guerrero and Chiapas. Accordingly, Montalvo-González et al. (2011) reported maximum values of SS of $15.0^{\circ}$ Brix for yellow plum and Tiburski et al. (2011) obtained an average of $14.9{ }^{\circ}$ Brix in yellow plum (Spondias mombin L.). An increase in the SS as fruit ripening process in Mexican plum and Brazilian has been reported by several authors (DANTAS et al., 2016; BAUTISTA-BAÑOS et al., 2003; PÉREZ et al., 2004; OSUNA et al., 2011).

Titratable acidity, both in pulp and epicarp, was higher in the green stage and significantly decreased as the fruit ripened from $0.48 \%$ to $0.27 \%$ in pulp and from $0.42 \%$ to $0.23 \%$ in the epicarp. These results coincide with those reported by Dantas et al. (2016), Díaz-Pérez et al. (1999), Filgueiras et al. (2001) and Pérez et al. (2004) who mentioned a decrease of titratable acidity as Mexican plum and Brazilian plums, fruit ripening process. Alia et al. (2012) obtained values between 0.2 and $2 \%$ of citric acid, while Tiburski et al. (2011) reported and average value of $1.46 \%$ of citric acid in yellow plum (Spondias mombin L.).

Mexican plum 'Cuernavaqueña' flavor index (FI) significantly increased with ripening stage both in pulp (from 12.35 to 87.62) and epicarp (from 18.47 to 105.16) (Table 1). The flavor index increase as a result of a decrease in TA and an increase in SS. Dantas et al. 2016, Filgueiras et al. (2001) and Pérez et al. (2004) reported a similar behavior. On another hand, Alia et al. (2012) reported a high variation $(\mathrm{VC}=66 \%$ ) on the FI going from 3.0 to 63.2 ; these results are attributed to the diversity of the evaluated genotypes.

The $1 / 2$ green and the $3 / 4$ ripe stages presented higher total phenols concentrations in the pulp, 89.21 and $77.7 \mathrm{mg}$ GAE $100 \mathrm{~g}^{-1}$ respectively, compared to the green and fully ripe stages (Table 2). On the other hand, the fully ripe stage showed the highest total phenols concentration in the epicarp $(190.6 \mathrm{mg}$ GAE $100 \mathrm{~g}^{-1}$ ). Filguerias et al. (2001) quantified the highest concentration of total phenols in the ripe stage of $S$. purpurea grown in Brazil with values between 160 and 240 mg GAE $100 \mathrm{~g}^{-1}$. Beserra et al. (2011) and Vieira et al. (2011) reported total phenols in Brazilian plum of $55.0 \pm 2.1,70.92 \pm 1.31 \mathrm{mg} \mathrm{GAE}$ $100 \mathrm{~g}^{-1}$, respectively. Tiburski et al. (2011) reported total phenols concentration in pulp of yellow plum (Spondias mombin) of $260 \mathrm{mg} \mathrm{GAE} 100 \mathrm{~g}^{-1}$. In the case of Mexican plum 'Cuernavaqueña', both the pulp and the epicarp are consumed, therefore the sum of the total phenol concentration of the pulp and the epicarp in ripe fruit make approximately $239 \mathrm{mg}$ GAE $100 \mathrm{~g}^{-1}$. Phenols in Spondias purpurea have a natural antioxidant function and its consumption provides benefits against chronic and degenerative diseases (FILGUEIRAS et al., 2001; TIBURSKI et al., 2011). Mexican plum total phenols content is higher to those reported for papaya (54 $\mathrm{mg} \mathrm{GAE}$ $100 \mathrm{~g}^{-1}$ ), banana (24-72 $\mathrm{mg}$ GAE $100 \mathrm{~g}^{-1}$ ) and

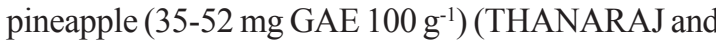
TERRY, 2011) and lower values $(284.25-154.40$ mg GAE $100 \mathrm{~g}^{-1}$ ) than Siqueira et al. (2015) in guanabana; therefore, it is considered a good source of metabolites with antioxidant capacity.

Flavonoids concentration in the pulp significantly increased from the green stage to the $3 / 4$ ripen and the fully ripe stages, from 17 to $23-22$ $\mathrm{mg}$ QE $100 \mathrm{~g}^{-1}$ (Table 2). The highest concentration of total flavonoids was observed in the epicarp of ripe plums with $214 \mathrm{mg} \mathrm{QE} 100 \mathrm{~g}^{-1}$ (Table 2). The total flavonoids content in ripe Mexican plum 'Cuernavaqueña' when the pulp and the epicarp flavonoids concentrations are added come to a total 
of approximately $245 \mathrm{mg} \mathrm{QE} 100 \mathrm{~g}^{-1}$ which is higher than the content reported for papaya (63.2 $\mathrm{mg} \mathrm{QE}$ $\left.100 \mathrm{~g}^{-1}\right)$, grape (55.9 mg EQ $\left.100 \mathrm{~g}^{-1}\right)$, açaí (70.1 mg QE $\left.100 \mathrm{~g}^{-1}\right)$ and strawberry (21.8 $\mathrm{mg}$ QE $100 \mathrm{~g}^{-1}$ ) (ZIELINSKI et al., 2014). These results suggest that Mexican plum provides important quantities of flavonoids when it is consumed.

Total carotenoids content increased both in pulp and in epicarp as fruit ripening progressed in Mexican plum 'Cuernavaqueña' from initial values between 37.29 and $150.71 \mu \mathrm{g} \mathrm{g}^{-1}$ to final values between 143.8 and $853.6 \mu \mathrm{g} \mathrm{g}^{-1}$, respectively (Table 2). A similar behavior was found by Solorzano et al. (2015). The sum of total carotenoids in pulp and epicarp of Mexican plum ripe fruit was of $1000 \mu \mathrm{g}$ $\mathrm{g}^{-1}$. Tibursky et al. (2011) reported total carotenoids of $4869.5 \mu \mathrm{g} \mathrm{g}^{-1}$ in yellow plum (Spondias mombin).

DPPH radical scavenging in pulp did not show significant differences among the four ripening stages with an average of $36.05 \mathrm{mg}$ AAE $100 \mathrm{~g}^{-1}$ and $396.62 \mu \mathrm{M}$ TE $100 \mathrm{~g}^{-1}$ (Table 3). In the ABTS assay, an increase on antioxidant activity in the pulp was observed in $1 / 2$ green and $3 / 4$ ripe stages (Table 3), while in the FRAP assay, antioxidant activity decreased in the pulp as ripening progresses (Table 3). Spínola et al. (2015) reported antioxidant activity determined by the ABTS method in different tropical fruits, cherimoya, lime, papaya, passion fruit and strawberry with values between 121.2 and 316.15 AAE $100 \mathrm{~g}^{-1}$ of juice and 675.14 and $1761.27 \mu \mathrm{mol}$ TE $100 \mathrm{~g}^{-1}$ of juice, respectively. The values obtained in Mexican plum 'Cuernavaqueña' compared to these data indicate that it has an acceptable antioxidant activity.

Antioxidant activity in epicarp of Mexican plum 'Cuernavaqueña' significantly increased as ripening progressed (Table 4). In the ripe stage, the epicarp showed the highest antioxidant activity against radicals DPPH, ABTS and FRAP. Kuskoski et al. (2005) reported antioxidant activity determined by DPPH in the pulp of tropical fruits (passion fruit, blackberry, pineapple, soursop, mango, grape) in the range of 174.3 to $41.1 \mathrm{mg} \mathrm{AAE} 100 \mathrm{~g}^{-1}$ and 12.9 to $0.5 \mu \mathrm{mol} \mathrm{TE} / \mathrm{g}$. For the ABTS assay, the same authors reported values between 37.0 and $224.7 \mathrm{mg}$ AAE $100 \mathrm{~g}^{-1}$ and 11.2 a $2.3 \mu \mathrm{mol} \mathrm{TE} \mathrm{g}{ }^{-1}$ which are similar to the values reported in the present work for Mexican plum. Tiburski et al. (2011) reported antioxidant activity of $17.47 \mathrm{mM} \mathrm{TE} \mathrm{g}^{-1}$ for yellow plum (Spondias mombin).

Mexican plum 'Cuernavaqueña' showed a good antioxidant activity with a higher free radical scavenging activity in the epicarp than in the pulp which can be attributed to the presence of higher levels of bioactive compounds such as phenols and carotenoids. Among the methods used to determine antioxidant activity for free radicals scavenging, the DPPH radical, ABTS and FRAP methods are the fastest. In some works the antioxidant activity is related to the content of phenols, flavonoids and carotenoids; however, there might be other compounds with antioxidant properties (vitamins, enzymes, minerals) in the sample matrix (SERRANO et al., 2007).

The correlation between the evaluated bioactive compounds and the antioxidant activity (mg AAE $\mathrm{g}^{-1}$ and $\mu \mathrm{M}$ TE100 $\mathrm{g}$ ) determined by three different methods was performed; a high and significant correlation between phenols, carotenoids and flavonoids present in the epicarp and its activity for radical scavenging was found (Table 5). Bioactive compounds show different antioxidant activity depending on their structure (number of hydroxyl groups) as well as the matrix in which they are found (HEO et al., 2007). Besides, Palafox-Carlos et al. (2012) reported the interaction between the major phenolic compounds found in 'Ataulfo' mango pulp, which results in a significant synergism in the antioxidant capacity.

Several works have related the antioxidant capacity with the content of total phenols, flavonoids and carotenoids present in food (FRANKEL and MEYER, 2000; IMEH and KHOKHAR, 2002; PALAFOX-CARLOS et al., 2012). There are several methods for determining the antioxidant activity and it has been observed that each method show different tendencies and that is the reason for the need to use more than one method. The methods most commonly used are ABTS and FRAP, these have affinity for compounds of both hydrophilic and hydrophobic nature; on another hand, DPPH is more selective for antioxidants with hydrophilic nature (SÁNCHEZMORENO, 2002).

The results obtained in this research show that phenols, flavonoids and carotenoids with antioxidant capacity are naturally present in Mexican plum fruit and their concentration varies according to the ripening stage which agrees with previous reports indicating that bioactive compounds vary depending on ripening stage, cultural and processing practices (FALLER and FIALHO, 2009; VILLARODRIGUEZ et al., 2010; GAYOSSO-GARCÍA et al., 2011). 
TABLE 1- Quality parameters in Mexican plum 'Cuernavaqueña' at four different ripening stages. Cuernavaca, 2014.

\begin{tabular}{ccccccccccc}
\hline $\begin{array}{c}\text { Ripening } \\
\text { stage }\end{array}$ & $\begin{array}{c}\text { Ethylene } \\
\mu \mathrm{L} \mathrm{kg} \mathrm{h}^{-1}\end{array}$ & $\begin{array}{c}\text { Respiration } \\
\mathrm{mL} \mathrm{kg} \mathrm{h}^{-1}\end{array}$ & $\mathrm{~L}^{*}$ & $\mathrm{C}^{*}$ & $\mathrm{~h}$ & $\begin{array}{c}\text { TSS } \\
{ }^{\circ} \text { Brix }\end{array}$ & $\begin{array}{c}\text { TA-P } \\
\%\end{array}$ & $\begin{array}{c}\text { TA-E } \\
\%\end{array}$ & FI- P & FI- E \\
\hline Green & $3.92 \mathrm{c}$ & $1.01 \mathrm{a}$ & $39.87 \mathrm{c}$ & $26.3 \mathrm{c}$ & $108.9 \mathrm{a}$ & $5.83 \mathrm{~d}$ & $0.48 \mathrm{a}$ & $0.42 \mathrm{a}$ & $12.35 \mathrm{c}$ & $18.47 \mathrm{c}$ \\
$1 / 2$ green & $5.81 \mathrm{bc}$ & $1.20 \mathrm{a}$ & $45.33 \mathrm{~b}$ & $34.4 \mathrm{~b}$ & $93.7 \mathrm{~b}$ & $10.1 \mathrm{c}$ & $0.4 \mathrm{a}$ & $0.32 \mathrm{~b}$ & $24.67 \mathrm{c}$ & $23.91 \mathrm{c}$ \\
3/4 ripe & $8.26 \mathrm{ab}$ & $1.03 \mathrm{a}$ & $50.3 \mathrm{a}$ & $43.3 \mathrm{a}$ & $75.2 \mathrm{c}$ & $18.7 \mathrm{~b}$ & $0.33 \mathrm{~b}$ & $0.26 \mathrm{bc}$ & $56.2 \mathrm{~b}$ & $71.7 \mathrm{~b}$ \\
Fully ripe & $9.43 \mathrm{a}$ & $1.23 \mathrm{a}$ & $45.91 \mathrm{~b}$ & $40.4 \mathrm{a}$ & $60.3 \mathrm{~d}$ & $23.9 \mathrm{a}$ & $0.27 \mathrm{~b}$ & $0.23 \mathrm{c}$ & $87.62 \mathrm{a}$ & $105.1 \mathrm{a}$ \\
\hline LSD & 3.39 & 0.4651 & 2.18 & 3.68 & 6.52 & 1.72 & 0.067 & 0.082 & 13.28 & 19.22 \\
VC (\%) & 23.7 & 22.96 & 2.98 & 6.30 & 4.52 & 7.29 & 9.89 & 14.45 & 16.23 & 19.37 \\
\hline
\end{tabular}

$L^{*}$ : lightness (0: white; 100: black); $\mathrm{C}^{*}$ : Chromaticity; $\mathrm{h}^{\circ}$ : hue angle $(0=$ red; 90 : yellow, 180 green); TSS: Total soluble solids TA-P: Titratable acidity in pulp; TA-E: Titratable acidity in epicarp; FI-P: flavor index in pulp; FI-E: flavor index in epicarp. LSD: Least Significant Difference; VC: Variation Coefficient. Means followed by different letters in each column are significantly different according to the Tukey test $P<0.05$.

TABLE 2- Bioactive compounds in Mexican plum 'Cuernavaqueña' at four different ripening stages. Cuernavaca, 2014.

\begin{tabular}{|c|c|c|c|c|c|c|}
\hline \multirow{2}{*}{$\begin{array}{l}\text { Ripening } \\
\text { stage }\end{array}$} & \multicolumn{3}{|c|}{ Pulp } & \multicolumn{3}{|c|}{ Epicarp } \\
\hline & $\begin{array}{c}\text { Phenols } \\
\left(\mathrm{mg} \mathrm{GAE} 100 \mathrm{~g}^{-1}\right)\end{array}$ & $\begin{array}{c}\text { Flavonoids } \\
\left(\mathrm{mg} \text { QE } 100 \mathrm{~g}^{-1}\right)\end{array}$ & $\begin{array}{c}\text { Carotenoids } \\
\left(\mu \mathrm{g} \mathrm{g}^{-1}\right)\end{array}$ & $\begin{array}{c}\text { Phenols } \\
\left(\mathrm{mg} \mathrm{GAE} 100 \mathrm{~g}^{-1}\right)\end{array}$ & $\begin{array}{c}\text { Flavonoids } \\
\left(\mathrm{mg} \text { QE } 100 \mathrm{~g}^{-1}\right)\end{array}$ & $\begin{array}{c}\text { Carotenoids } \\
\left(\mu \mathrm{g} \mathrm{g}^{-1}\right)\end{array}$ \\
\hline Green & $48.71 \mathrm{~b}$ & $17.11 \mathrm{c}$ & $37.29 \mathrm{c}$ & $91.4 \mathrm{~d}$ & $175.91 \mathrm{~b}$ & $143.8 \mathrm{~d}$ \\
\hline $1 / 2$ green & $89.21 \mathrm{a}$ & $19.27 \mathrm{bc}$ & $43.64 \mathrm{c}$ & $117.17 \mathrm{c}$ & $169.62 \mathrm{~b}$ & $390.9 \mathrm{c}$ \\
\hline $3 / 4$ ripe & $77.7 \mathrm{a}$ & $23.26 \mathrm{a}$ & $92.21 \mathrm{~b}$ & $161.5 \mathrm{~b}$ & $176.35 \mathrm{~b}$ & $582.7 \mathrm{~b}$ \\
\hline Fully ripe & $48.1 \mathrm{~b}$ & $22.07 \mathrm{ab}$ & $150.71 \mathrm{a}$ & $190.65 \mathrm{a}$ & $214.7 \mathrm{a}$ & $853.6 \mathrm{a}$ \\
\hline$\overline{L S D}$ & 21.92 & 3.66 & 19.95 & 13.0 & 29.16 & 154.8 \\
\hline VC (\%) & 20.76 & 11.09 & 13.62 & 5.66 & 9.77 & 17.36 \\
\hline
\end{tabular}

GAE: Gallic Acid Equivalents; QE: Quercetin Equivalents. Means followed by different letters in each column are significantly different according to the Tukey test $P<0.05$. LSD: Least Significant Difference, VC: Variation Coefficient.

TABLE 3 - . Antioxidant activity in the pulp of Mexican plum 'Cuernavaqueña' at four different ripening stages. Cuernavaca, 2014.

\begin{tabular}{|c|c|c|c|c|c|c|}
\hline \multirow[b]{2}{*}{$\begin{array}{l}\text { Ripening } \\
\text { stage }\end{array}$} & \multicolumn{6}{|c|}{ Pulp } \\
\hline & DPPH & ABTS & FRAP & DPPH & ABTS & FRAP \\
\hline & $\operatorname{mg}$ AAE $100 \mathrm{~g}^{-1}$ & mg AAE $100 \mathrm{~g}^{-1}$ & mg AAE $100 \mathrm{~g}^{-1}$ & $\mu \mathrm{M}$ TE $100 \mathrm{~g}^{-1}$ & $\mu \mathrm{M}$ TE $100 \mathrm{~g}^{-1}$ & $\mu \mathrm{M}$ TE $100 \mathrm{~g}^{-1}$ \\
\hline Green & $36.97 \mathrm{a}$ & $43.4 \mathrm{c}$ & $84.41 \mathrm{ab}$ & $398.63 a$ & $401.17 \mathrm{c}$ & $814.60 \mathrm{ab}$ \\
\hline $1 / 2$ green & $36.92 \mathrm{a}$ & $61.5 \mathrm{ab}$ & $90.48 \mathrm{a}$ & $399.12 \mathrm{a}$ & $563.3 \mathrm{ab}$ & $881.18 \mathrm{a}$ \\
\hline $3 / 4$ ripe & $37.64 \mathrm{a}$ & $73.7 \mathrm{a}$ & $73.69 \mathrm{~b}$ & $405.75 \mathrm{a}$ & $673.84 \mathrm{a}$ & $697.15 \mathrm{~b}$ \\
\hline Fully ripe & $32.53 \mathrm{a}$ & $57.37 \mathrm{bc}$ & $56.63 \mathrm{c}$ & $383.99 a$ & $524.58 \mathrm{bc}$ & $56.63 \mathrm{c}$ \\
\hline LSD & 15.67 & 15.56 & 14.94 & 170.94 & 136.47 & 164.83 \\
\hline $\mathrm{VC}(\%)$ & 26.04 & 15.94 & 10.83 & 26.66 & 15.61 & 12.55 \\
\hline
\end{tabular}

Ascorbic acid equivalent (AAE); Trolox equivalent (TE). LSD: Least Significant Difference, VC: Variation Coefficient. 
TABLE 4- Antioxidant activity in the epicarp of Mexican plum 'Cuernavaqueña' at four different ripening stages. Cuernavaca, 2014.

\begin{tabular}{|c|c|c|c|c|c|c|}
\hline \multirow{3}{*}{$\begin{array}{l}\text { Ripening } \\
\text { stage }\end{array}$} & \multicolumn{6}{|c|}{ Epicarp } \\
\hline & DPPH & ABTS & FRAP & $\mathrm{DPPH}$ & ABTS & FRAP \\
\hline & $\operatorname{Mg}$ AAE $100 \mathrm{~g}^{-1}$ & mg AAE $100 \mathrm{~g}^{-1}$ & mg AAE $100 \mathrm{~g}^{-1}$ & $\mu \mathrm{M}$ TE $100 \mathrm{~g}^{-1}$ & $\mu \mathrm{M}$ TE $100 \mathrm{~g}^{-1}$ & $\mu \mathrm{M}$ TE $100 \mathrm{~g}^{-1}$ \\
\hline Green & $51.79 \mathrm{c}$ & $76.5 \mathrm{~d}$ & $93.92 \mathrm{~d}$ & $556.8 \mathrm{c}$ & $698.44 \mathrm{~d}$ & $918.8 \mathrm{~d}$ \\
\hline $1 / 2$ green & $65.5 \mathrm{bc}$ & $101.6 \mathrm{c}$ & $111.7 \mathrm{c}$ & $702.99 \mathrm{bc}$ & $925.2 \mathrm{c}$ & $1114.79 \mathrm{c}$ \\
\hline $3 / 4$ ripe & $75.86 \mathrm{~b}$ & $133.4 \mathrm{~b}$ & $141.9 \mathrm{~b}$ & $813.52 \mathrm{~b}$ & $1210.9 \mathrm{~b}$ & $1447.2 \mathrm{~b}$ \\
\hline Fully ripe & $98.87 \mathrm{a}$ & $167.4 \mathrm{a}$ & $170.7 \mathrm{a}$ & $1087.6 \mathrm{a}$ & $1534.7 \mathrm{a}$ & $1764.4 \mathrm{a}$ \\
\hline DMS & 16.18 & 20.7 & 15.73 & 172.73 & 179.92 & 172.59 \\
\hline CV (\%) & 13.53 & 10.57 & 6.7 & 13.56 & 10.19 & 7.27 \\
\hline
\end{tabular}

Ascorbic acid equivalent (AAE); Trolox equivalent (TE). LSD: Least Significant Difference, VC: Variation Coefficient.

TABLE 5-Positive Pearson correlation coefficients and level of significance between bioactive compounds and antioxidant activity. Cuernavaca, 2014.

\begin{tabular}{|c|c|c|c|c|c|}
\hline & DPPH E & ABTS E & FRAP E & ABTS P & FRAP P \\
\hline Phenols E & $\begin{array}{c}{ }_{\text {A } 0.85 * * *} \\
\text { в } 0.871 * * *\end{array}$ & $\begin{array}{l}\text { A } 0.94 * * * \\
\text { B } 0.95 * * *\end{array}$ & $\begin{array}{l}\text { A } 0.941 * * * \\
\text { в } 0.943 * * *\end{array}$ & & \\
\hline Flavonoids E & $\begin{array}{l}\text { B } 0.68 * * * \\
\text { А } 0.625 * *\end{array}$ & $\begin{array}{l}\text { B } 0.649 * * * \\
{ }_{\mathrm{B}} 0.601 * *\end{array}$ & & & \\
\hline Carotenoids E & $\begin{array}{l}\text { В } 0.81 * * * \\
\text { B } 0.76 * * *\end{array}$ & $\begin{array}{l}\text { А } 0.907 * * * \\
\text { в } 0.884 * * * *\end{array}$ & $\begin{array}{l}{ }_{\mathrm{A}} 0.87 * * * \\
{ }_{\mathrm{B}} 0.89 * * *\end{array}$ & & \\
\hline Phenols P & & & & & $\begin{array}{r}{ }^{A} 0.56^{* *} \\
0.565 * *\end{array}$ \\
\hline Flavonoids P & & & & $\begin{array}{l}0.561 * * \\
{ }_{\mathrm{B}} 0.555 * *\end{array}$ & \\
\hline Carotenoids P & & & & & $\begin{array}{l}0.83 * * * \\
{ }_{\mathrm{A}} 0.83 * * *\end{array}$ \\
\hline
\end{tabular}

\section{REFERENCES}

ALIA, T.I.; MALDONADO, A.Y.I.; NÚÑEZ, C.C.A.; VALDEZ, A.L.A.; BAUTISTA, B.S.; GARCÍA, V.E.; ARIZA, F.R.; RIVERA, C.F. Caracterización de frutos de ciruela mexicana (Spondias purpurea L.) del sur de México. Revista Fitotecnia Mexicana, México, v. 35, n. 5, p. 21-26, 2012.

ARVOUET-GRAND, A.; VENNAT, B.; POURRAT, A.; LEGRET, P. Standardisation dun extrait de propolis et identification des principaux constituants. Journal of Pharmacie Belgique, Clermont-Ferrand, v. 49, n.6, p. 462-468, 1994.
AOAC - Association Official Analytical Chemists. Official methods of analysis of the association of official analytical chemistry. 16th ed. Washington, 1995.

AVITIA-GARCÍA, E.; CASTILLO-GONZÁLEZ, A. M.; PIMIENTA-BARRIOS, E. Ciruela mexicana y otras especies del género Spondias $L$. Primera edición. México: Edit. Universidad Autónoma Chapingo. 2000, p.75.

BAUTISTA-BAÑOS, S.; DÍAZ-PÉREZ, J.C.; BARRERA-NECHA, L.L.; BRAVO-LUNA, L. Postharverst study of red-mombin (Spondias pupurea) fruit during storage. Revista Iberoamericana de Tecnología Postcosecha, Hermosillo, v.5, n.2, p.8285, 2003. 
BENZIE, I.F.F.; STRAIN, J.J. The ferric reducing ability of plasma (FRAP) as a measure of "Antioxidant Power": The FRAP assay. Analytical. Biochemistry, Bethesda, v. 239, n. 1, p. 70-76, 1996.

BRAND-WILLIAMS, W.; CULIVIER, M.E.; BERSET, C. Use of a free radical method to evaluate antioxidant activity. Lebensmittel Wissenschaft and Technologie. Food Science Technology, London, v.28, n.1, p.25-30, 1995.

DANTAS, L.A.; SILVA D.M.S.; DANTAS, L.R.; DE SOUSA, B.S.A.; SCHUNEMANN, P.P.A. Development physiology of maturation and indication of harvest point of umbuguela tree fruits (Spondias sp.). Revista Brasileira de Fruticultura, Jaboticabal, v. 38, n. 1, p. 033-42, 2016.

DÍAZ-PÉREZ, J.C.; ZAVALETA, R.; BAUTISTA, S.; AGUILAR, B.; SEBASTIÁN, V. Cambios físico-químicos de ciruela mexicana (Spondias purpurea L.) cosechada en dos diferentes estados de madurez. Revista Iberoamericana de Tecnología Postcosecha, Hermosillo, v.1, n.1, p.19-24, 1999.

FALLER, A.L. K.; FIALHO, E. The antioxidant capacity and polyphenol content of organic and conventional retail vegetables after domestic cooking. Food Research International, Campinas, v. 42, n.1, p. 210-215, 2009.

FILGUEIRAS, H.A.C.; ALVES, R.E.; MOURA, C.F.H.; OLIVEIRA, A.C.; ARAÚJO, N.C.C. Calidad de frutas nativas de Latinoamérica para industria: Ciruela mexicana (Spondias pururea L.). Proccedings of the Interamerican Society for Tropical Horticulture, Brasil, v. 43, p.68-71, 2001.

FRANKEL, E.; MEYER, A. The problems of using one-dimensional methods to evaluate multifunctional food and biological antioxidants. Journal of the Science of Food and Agriculture, United States, v.80, n.13, p.1925-1941, 2000.

GAYOSSO-GARCÍA S, L.E.; YAHIA, E, M.; GONZÁLEZ-AGUILAR, G,A. Identification and quantification of phenols, carotenoids and vitamin $\mathrm{C}$ from papaya (Carica papaya $\mathrm{L}$, cv Maradol) fruit determined by HPLC-DAD-MS/MS- ESI. Food Research International, Toronto, v.44, p.12841291, 2011.
HEO, H.; KIM, Y.; CHUNG, D.; KIM, D. Antioxidant capacities of individual and combined phenolics in a model system. Food Chemistry, London, v. 104, p. 87-92, 2007.

HIWASA-TANASE, K.; EZURA, H. Fruit Ripening Physiology, Signalling and Genomics: Climateric and Non-climacteric Ripening. CABI. Boston, MA, USA. 2014 p. 1-14.

HOOPER, L.; CASSIDY, A. A review of the health care potential of bioactive compounds. Journal of the Science of Food and Agriculture, Davis, v. 86, n. 12, p. 1805-1813, 2006.

IMEH, U.; KHOKHAR S. Distribution of conjugated and free phenols in fruits: antioxidant activity and cultivar variations. Journal of Agricultural and Food Chemistry, Washington, v. 50, n, 22, p. 63016306, 2002.

ISABELLE, M.; LEE, B,L.; LIM, H,T.; KOH, W. P.; HUANG, D.; ONG, C.N. Antioxidant activity and profiles of Common Fruits in Singapore. Food Chemistry, London, v. 123, n.4, p. 77-84, 2010.

KUSKOSKI, M.E.; ASUERO, G.A.; TRONCOSO, M.A.; MANCINI-FILHO J.; FETT R. Aplicación de diversos métodos químicos para determinar actividad antioxidante en pulpa de frutos. Ciencia e Tecnologia de Alimentos, Campinas, v. 25, n. 4, p. 726-732, 2005.

KOHATSU, D.S.; ZUCARELI, V.; BRAMBILLA, W.P.; EVANGELISTA, R. M.; ONO, E.O.; DA SILVA, T. R. B. Storage temperature and quality of red mombin (Spondias purpurea L.). International Journal of Food, Agriculture and Environment, Finland, v. 9, n. 3-4, p. 20-22. 2011.

MALDONADO, A.Y.I.; ALIA, T. I.; NÚÑEZ, C. C. A.; JIMÉNEZ, H, J.; PELAYO, Z. C.; LÓPEZ, M.V.; ANDRADE, R. M.; BAUTISTA, B. S.; VALLE, G. S. Postharvest physiology and technology of Spondias purpurea L. and S. mombin L. Scientia Horticulturae, Amsterdan, v. 174, p. 193-206, 2014.

MENDOZA-WILLSON A.M.R.; BAÉZ-SAÑUDO. 2000. Medición de la tasa respiratoria en sistema cerrado en melón cantaloupe. Horticultura Mexicana, México, v. 8, p.158-163, 2000. 
McGuire, R.G. Reporting of objective color measurements. HortScience, Alexandria, v. 27, n. 12 p. 1254-1255, 1992.

MONTALVO-GONZÁLEZ, E.; GARCÍA, H.S.; MATA-MONTES DE OCA.; TOVAR-GÓMEZ, B. Efecto de la luz en ciruela mexicana manejada en diferentes condiciones de almacenamiento. CyTAJournal of Food, México, v. 9, n. 1 p. 65-70, 2011.

NIVA, M. "All foods affect health": Understandings of functional foods and healthy eating among healthoriented Finns. Appetite, Finland, v. 48, n. 3, p. 384-393, 2007.

OSUNA G.J.A.; PÉREZ, B.M.H.; VÁZQUEZ, V.V.; GÓMEZ, J.R. Application of 1-methylcyclopropene (1-MCP) on Mexican Plum (Spondias purpurea L.). Revista Fitotecnia Mexicana, México, v. 34, n. 3, p. $197-204,2011$.

PALAFOX-CARLOS, H.; GIL-CHÁVEZ, J.; SOTELO-MUNDO, R.R.; NAMIESNIK, J., GORINSTEIN, S.; GONZÁLEZ-AGUILAR, G.A. Antioxidant interactions between major phenolic compounds found in 'Ataulfo' mango pulp: chlorogenic, gallic, protocatechuic and vanillic acids. Molecules, Basel, v.17, n. 11, p. 12657-12664, 2012.

PALAFOX-CARLOS, H.; YAHIA E.; ISLASOSUNA, M.A.; GUTIÉRREZ-MARTINEZ, P.; ROBLES-SÁNCHEZ, M.; GONZÁLEZAGUILAR, G.A. Effect of ripeness stage of mango fruit (Mangifera indica L., cv Ataulfo) on physiological parameters and antioxidant activity. Scientia Horticulturae, Amsterdam, v.135, n.24, p.7-13, 2012.

PEREIRA, E.C.P.; FILGUEIRAS, H.A.C.; ALVES, R.E. Actividad respiratoria y producción de etileno postcosecha de ciruela mexicana y jobo. Revista Iberoamericana de Tecnología Poscosecha, México, v. 2, p.155-160, 2000.

PÉREZ, L.A.; SAUCEDO, V.C.; ARÉVALO, G.M.L.; MURATALLA, L.A. Efecto del grado de madurez en la calidad y la vida postcosecha de ciruela mexicana Spondias purpurea L. Revista Fitotecnia Mexicana, México, v. 27, n. 2, p.133-139, 2004.
PRIOR, R.L; WU, X.; SCHAICH, K. Standardized methods for the determination of antioxidant capacity and phenolics in foods and dietary supplements. Journal of Agricultural and Food Chemistry, Washington, v.53, n.10, p. 4290-4302, 2005.

RE, R.; PELLEGRINI, N.; PROTEGGENTE, A.; PANNALA, A.; YANG, M.; RICE-EVANS, C. Antioxidant activity applying an improved ABTS radical cation decolorization assay. Free Radical Biology and Medicine, New York, v. 26, p. 12311237, 1999.

RODRÍGUEZ-AMAYA, D.B.; KIMURA, M. 2004. HarvestPlus Handbook for Carotenoid Analysis. HarvestPlus Technical Monograph Series 2. Screening Method for Sweetpotato and Cassava. Brasil. HarvestPlus, 2004. p. 35-36.

\section{SALTVEIT, M.E.}

SÁNCHEZ-MORENO, C. Review: methods used to evaluate the free radical scavenging activity in foods and biological systems. Food Science and Technology International, Madrid, v. 8 n. 3, p, 121-39, 2002.

SERRANO, J.; GONI I.; SAURA-CALIXTO F. Food antioxidant capacity determined by chemical methods may underestimate the physiological antioxidant capacity. Food Research International, Spain, v. 40, p. 15-21, 2007.

SINGLETON, V.L.; ORTHOFER, R.; LAMUELARAVENTOS, R.M. Analysis of total phenols and other oxidation substrates and antioxidants by means of Folin-Ciocalteu reagent. Methods in Enzymology, London, v. 299, p, 152-178, 1999.

SIQUEIRA, O.M.D.A.; MOREIRA, G.C.C.A.; MELO,A.D.E.; STAMFORD, M.C.T.; STAMFORD, M.L.T. Dietary fibre content, phenolic compounds and antioxidant activity in Soursops (Annona muricata L.). Revista Brasileira de Fruticultura, Jaboticabal, v. 37, n. 4, p. 1020-1026, 2015.

SOLORZANO-MORÁN, S.; ALIA-TEJACAL, I.; RIVERA-CABRERA, F.; LÓPEZ-MARTÍNEZ, V.; PÉREZ-FLORES, L. J.; PELAYO-ZALDÍVAR, C.; MALDONADO-ASTUDILLO, Y. I. Quality attributes and functional compounds of Mexican plum (Spondias purpurea L.) fruit ecotypes. Fruits, Les Ulis, v. 70, p. 261-270, 2015. 
SPÍNOLA, V.; PINTO, J.; CASTILLO, C. P. Identification and quantification of phenolic compounds of selected fruits from Madeira Island by HPLC-DAD-ESI-MS ${ }^{\mathrm{n}}$ and screening for their antioxidant activity. Food Chemistry, London, v. 173, p, 14-30, 2015.

THANARAJ, T.; TERRY, L.A. Tropical fruits (Banana, pineapple, papaya and mango). Healthpromoting properties of fruit and vegetables. Terry, A. L (ed), CABI, Wallingford, UK. 2011. p, 352-370.

TIBURSKI, J.H.; ROSENTHAL, A.; DELIZA, R., GODOY, R.L.O.; PACHECO, S. Nutritional properties of yellow mombin (Spondias mombin L.) pulp. Food Research International, Ottawa, v. 44, p. 2326-2331, 2011.

VIEIRA, M.L.; SOUSA, B.S.M.; MANANI-FILHO, J.; LIMA, D.A. Total phenolics and antioxidant capacity "In vitro" of tropical fruit pulps. Revista Brasileira de Fruticultura, Jaboticabal, v. 33, n. 3, p. 888-897, 2011.
VILLA-RODRÍGUEZ, J.A.; MOLINA-CORRAL, F. J.; AYALA-ZAVALA, J.F.; OLIVAS, G. I.; GONZÁLEZ-AGUILAR, G. A. Effect of maturity stage on the content of fatty acids and antioxidant activity of 'Hass' avocado. Food Research International, Toronto, v.44, n. 5, p. 1231-1237, 2011.

ZIELINSKI, A.A.F.; ÁVILA, S.; ITO, V.; NORIEGA, A.; WOSIACKI, G.; HAMINIUK, C.W.I. The Association between Chromaticity, Phenolics, Carotenoids, and In Vitro Antioxidant Activity of Frozen Fruit Pulp in Brazil: An Application of Chemometrics. Journal of Food Science, Chicago, v. 79, n. 4, p. C510-C516, 2014. 